\title{
PERANAN KELOMPOK PETERNAK TERHADAP USAHA PENGEMBANGAN TERNAK ITIK DI KECAMATAN TONDANO BARAT KABUPATEN MINAHASA
}

\author{
Suzeth G. Tinenta; S. O. B. Lombogia*, F. S. Oley, J. M. Tumewu \\ Fakultas Peternakan Universitas Sam Ratulangi Manado, 95115
}

\begin{abstract}
ABSTRAK
Pembangunan peternakan secara umum yaitu untuk meningkatkan taraf hidup masyarakat pedesaan terutama petani peternak. Usaha yang dilakukan adalah peningkatkan produksi peternakan dan untuk memenuhi kebutuhan gizi masyarakat yang ada di pedesaan. Untuk mengubah cara pemeliharaan dari tradisional kearah pemeliharaan yang profesional (intensif), diperlukan suatu pemahaman dan pengetahuan tentang beternak itik yang baik.

Penelitian ini dilaksanakan pada kelompok peternak itik di Desa Tuutu Kecamatan Tondano Barat Kabupaten Minahasa. Penelitian dilaksanakan sejak tanggal 10 Januari 2017 sampai dengan 10 April 2017. Penelitian ini menggunakan penelitian kualitatif dengan pendekatan secara fenomenologis. Dalam penelitian kualitatif, sumber data dipilih secara sengaja (purposive Sampling). Data yang di gunakan adalah data primer dan sekunder. Data primer diperoleh melalui pengamatan langsung dilapangan dan mengadakan wawancara dengan responden (peternak itik) dengan berpedoman pada pertanyaan yang telah disiapkan dan disusun sesuai dengan tujuan penelitian.
\end{abstract}

*Korespondensi (Corresponding Author) Email: lombogiastanly@yahoo.co.id
Data sekunder diperoleh dari catatan-catatan yang ada di Kantor Camat dan Kantor BP3K setempat. Berdasarkan hasil penelitian menunjukkan bahwa semua kelompok peternak itik di desa Tuutu Kecamatan Tondano Barat Kabupaten Minahasa berperan dalam pengembangan usaha ternak itik, karena dalam pengambilan keputusan, selalu melibatkan kelompok. Kelompokkelompok tersebut adalah kelompok Masawa-Sawangan, Tougela, Esa Toroan Waya dan Toubeke.

Kata kunci : Kelompok tani, ternak itik, pengembangan

\section{ABSTRACT}

\begin{tabular}{|c|c|c|}
\hline FARMER & GROUP & $\mathbf{O N}$ \\
\hline DEVELOPN & ENT $\quad$ OF & DUCK \\
\hline FARMING & SYSTEM IN & WES \\
\hline TONDANO & DISTRICT & O \\
\hline
\end{tabular}

MINAHASA REGENCY. Development of animal husbandry was generally intended to improve the human welfare of rural community, mainly increasing the productivity their animal farming system. This effort was mainly done to fulfil the nutritional needs of the communities in rural areas. The animal farming system was changed from the traditional way of animal maintenance into the intensive maintenance, requiring better understanding and knowledge of raising ducks. This research was carried out at the village of Tuutu, West Tondano district of Minahasa regency involving duck household farmer group from January 10, 2017 - 10 April 2017. This research was applied using qualitative research. Data 
were collected intentionally based on purposive Sampling method, collected from primary and secondary sources of data. Primary data were obtained through direct observation held by interviews with the respondents of duck household farmers applying questions that have been prepared and drawn up in accordance with the research objectives. Secondary data were obtained from existing records in the Office of the head of the local Office and BP3K related with this study. Results of the study showed that all duck household farmer groups at the village of Tuutu, West Tondano district of Minahasa Regency were playing role in development of duck household farming system in making decision, involving the group. These groups were including four groups of Masawa-Sawangan, Tougela, Esa Toroan Waya and Toubeke.

Key word: Household farming group, duck farming system development, West Tondano district

\section{PENDAHULUAN}

Pembangunan peternakan secara umum, dimaksudkan untuk meningkatkan taraf hidup masyarakat pedesaan terutama peternak, dengan cara meningkatkan produksi peternakannya. Disamping itu, dilakukan usaha untuk memenuhi kebutuhan akan gizi masyarakat yang ada di pedesaan. Selanjutnya, untuk mengubah cara pemeliharaan dari tradisional kearah pemeliharaan yang intensif, diperlukan suatu pemahaman dan pengetahuan beternak itik yang lebih baik. Hal ini secara bersamaan berperan dalam menciptakan lapangan pekerjaan di masyarakat pedesaan. Untuk memenuhi kebutuhan protein hewani, maka pemerintah dan peternak telah berusaha mendayagunakan berbagai sumber protein ternak seoptimal mungkin. Dari sekian banyak jumlah dan jenis ternak yang dikembangkan, maka usaha ternak itik juga merupakan salah satu alternatif yang dapat dipilih untuk diusahakan dan di kembangkan.

Pedoman penyelenggaraan penyuluhan pertanian, yang diharapkan dapat menumbuhkan kelompok peternak sesuai dengan kondisi dan potensi sumber daya setempat, serta memperhatikan lingkungan strategis yang mempengaruhinya (Dinas Peternakan, 1998). Pembentukan wadah kelompok didukung oleh keputusan bersama Mendagri dan Mentri Pertanian No. 54 tahun 1996 dan 301/KPTS/L.p.120/4/96. Hal ini merupakan gambaran dan yang menjadi perhatian, untuk peternak dalam membentuk wadah kelompok dengan tujuan untuk mengubah sikap, pengetahuan dan keterampilan dalam usaha tani serta untuk menambah penghasilan keluarga.

Dinamika kelompok peternak adalah gerakan bersama yang dilakukan oleh anggota kelompok secara serentak dan bersama-sama melaksanakan seluruh kegiatan kelompok dalam mencapai tujuannya yaitu peningkatan hasil produksi 
dan mutunya yang giliranya nanti akan meningkatkan pendapatan mereka.

Dinamika kelompok mencakup seluruh kegiatan meliputi inisiatif daya kreatif dan tindakan nyata yang dilakukan oleh pengurus dan anggota kelompok dalam melaksanakan rencana kerja kelompoknya yang telah di sepakati bersama (Suhardiyono 1992). Ciri-ciri kelompok yang dinamis yaitu kelompok yang memiliki tujuan kelompok, struktur kelompok, fungsi dan tugas kelompok, pembinaan kelompok, kekompakan kelompok, suasana kelompok, tekanan pada kelompok, efektifitas pada kelompok.

Penelitian dilakukan di Kecamatan Tondano Barat, penentuan Kecamatan sampel dilakukan secara purposive sampling dengan pertimbangan Kecamatan yang memiliki populasi itik terbesar. Untuk mengetahui dimana kecamatan yang memiliki populasi itik terbesar di Kecamtan Tondano Barat, peneliti mengambil data dari Kantor Camat Tondano Barat, (Minahasa dalam angka, 2016) Dapat dilihat di Tabel 1.

Tabel 2 diketahui populasi ternak itik yang dimiliki setiap desa diwilayah Kecamatan Tondano Barat. Desa Tuutu sebagai desa sampel karena miliki populasi itik yang terbanyak. Pengambilan sampel dilakukan secara purposive sampling dengan kriteria desa tersebut memiliki populasi itik terbesar dan memiliki peternak itik terbanyak di Kecamatan Tondano Barat. Untuk mengetahui dimana populasi itik terbanyak di tingkat desa, peneliti mengambil data dari Kantor BP3K Tondano Barat dalam data yang diambil populasi itik disajikan dari tingkat desa yang berada di wilayah Kecamatan Tondano Barat. Ternak itik telah menjadi salah satu pilihan usaha sebagai penyedia telur dan daging sehingga dapat dijadikan ternak andalan (Kateran 2002).

Tabel 1. Populasi Penduduk di Kecamatan Tondano Barat Kabupaten Minahasa

\begin{tabular}{clrrc}
\hline No & \multicolumn{1}{c}{ Kelurahan } & Laki-laki & Perempuan & Seks Rasio \\
\hline 1 & Masarang & 505 & 441 & 115 \\
\hline 2 & Tuutu & 765 & 760 & 101 \\
\hline 3 & Roong & 929 & 936 & 99 \\
\hline 4 & Rinegetan & 1556 & 1570 & 99 \\
\hline 5 & Tounkuramber & 593 & 619 & 96 \\
\hline 6 & Wawalintoan & 1933 & 1918 & 101 \\
\hline 7 & Rerewokan & 989 & 959 & 103 \\
\hline 8 & Watulambot & 1286 & 1221 & 105 \\
\hline 9 & Wewelen & 1352 & 1366 & 99 \\
\hline & Jumlah & 9908 & 9790 & 101
\end{tabular}

Sumber: Kantor Camat Tondano Barat Kabupaten Minahasa 2016 


\section{METODE PENELITIAN}

\section{Lokasi Dan Waktu Penelitian}

Penelitian ini dilaksanakan di kelompok peternak itik di Desa Tuutu Kecamatan Tondano Barat Kabupaten Minahasa yang berlangsung dari 10 Januari 2017 - 10 April 2017.

\section{Metode Pengumpulan Data}

Teknik pengumpulan data dengan menggunakan metode survei. Survei adalah suatu proses pengumpulan informasi dari narasumber (peternak) pada suatu populasi dengan harapan akan diperoleh data yang akurat dengan menggunakan kuesioner sebagai alat pengumpulan data. Sumber data yang diambil adalah melalui data primer dan data sekunder. Data primer diperoleh melalui pengamatan langsung kelapangan dan mengadakan wawancara mendalam dengan responden yaitu peternak itik dengan berpedoman pada pertanyaan yang telah disiapkan dan disusun sesuai dengan tujuan penelitian. Data sekunder diperoleh melalui instansi-instansi yang ada hubungannya dengan penelitian. (Singarimbun dan Effendi, 1999).

\section{Metode Penentuan Narasumber}

Penentuan narasumber dilakukan secara Purposive Sampling yaitu desa yang mempunyai kelompok tani ternak itik, berdasarkan data dari Pos Keswan
Kecamatan Tondano Kabupaten Minahasa.

Data dari Pos kesehatan hewan Kecamatan Tondano Barat Kabupaten Minahasa terdapat 8 kelompok peternak itik. Narasumber yang dipilih yaitu kelompok tani ternak itik di desa Tuutu, dengan jumlah kelompok tani ternak itik 4 (empat) kelompok.

\section{Model Analisis Data Kualitatif}

Analisis data kualitatif dengan pendekatan fenomenologis adalah proses mencari dan menyusun secara sistematis data yang diperoleh dari hasil wawancara mendalam, catatan lapangan dan dokumentasi, dengan cara mengorganisasikan data ke dalam kategori, menjabarkan ke dalam unit-unit, melakukan sintesa, menyusun ke dalam pola, memilih mana yang penting dan yang akan dipelajari, dan membuat kesimpulan sehingga mudah dipahami oleh diri sendiri dan orang lain. Model analisis data dalam penelitian ini mengikuti konsep Miles and Huberman. Miles and Huberman mengungkapkan bahwa aktifitas dalam analisis data kualitatif dilakukan secara interaktif dan berlangsung secara terusmenerus pada setiap tahapan penelitian sehingga sampai tuntas.

\section{Letak Geografi dan Iklim}

Kecamatan Tondano Barat terletak antara $1^{\circ} 29^{1}$ sampai $1^{\circ} 32^{1}$ Lintang Utara dan antara $124^{\circ} 88^{1}$ sampai $124^{\circ} 92^{1}$ Bujur 
Timur. Kecamatan Tondano Barat memiliki batas-batas sebagai berikut:

- Sebelah Utara : Kecamatan Tondano Utara

- Sebelah Timur : Kecamatan Tondano Timur

- Sebelah Selatan :Kecamatan Tondano Selatan

- Sebelah Barat : Kota Tomohon

Rata-rata temperatur di Tondano Barat sepanjang tahun 2016 adalah sekitar $21^{\circ} \mathrm{C}$ sampai $32^{\circ} \mathrm{C}$. Desa Tuutu merupakan satu kelurahan yang berada di Kecamatan
Tondano Barat, Kabupaten Minahasa, Provinsi Sulawesi Utara, Indonesia.

Tabel 3 menunjukan bahwa Kecamatan Tondano Barat terdiri dari 9 kelurahan yaitu: Masarang, Tuutu, Roong, Rinegetan, Tounkuramber, Wawalintouan, Rerewokan, Watulambot, dan Wewelan.

Dari 9 desa yang ada di Kecamatan Tondano Barat yang menjadi lokasi penelitian adalah desa Tuutu dengan luas lahan $318,82 \mathrm{Ha}$.

Tabel 2. Populasi Ternak di Kecamatan Tondano Barat Kabupaten Minahasa

\begin{tabular}{|c|c|c|c|c|c|c|c|c|}
\hline \multirow{3}{*}{ No } & \multirow{3}{*}{ Kelurahan } & \multicolumn{7}{|c|}{ Jenis Ternak (Ekor) } \\
\hline & & \multicolumn{5}{|c|}{ Ternak Besar/Ternak Kecil } & \multicolumn{2}{|c|}{ Ternak Unggas } \\
\hline & & Sapi & Kuda & Babi & $\begin{array}{l}\text { Kam } \\
\text { bing }\end{array}$ & Anjing & $\begin{array}{l}\text { Ayam } \\
\text { Buras }\end{array}$ & Itik \\
\hline 1. & Roong & 6 & 6 & 18 & - & 224 & 1680 & 4680 \\
\hline 2. & Tuutu & 4 & 3 & 8 & - & 268 & 130 & 17.800 \\
\hline 3. & Rinegetan & 5 & 2 & 6 & - & 160 & 426 & 85 \\
\hline 4. & Tounkuramber & - & 3 & 4 & 3 & 168 & 670 & 160 \\
\hline 5. & Wawalintoan & 16 & 2 & 12 & 2 & 410 & 630 & 270 \\
\hline 6. & Rerewokan & 5 & 12 & 27 & 9 & 215 & 393 & - \\
\hline 7. & Watulambot & 23 & 6 & 44 & - & 380 & 615 & 1.120 \\
\hline 8. & Wewelen & 54 & 5 & 48 & - & 342 & 390 & - \\
\hline \multirow[t]{2}{*}{9.} & Masarang & 15 & 2 & 15 & - & 105 & 510 & 67 \\
\hline & Jumlah & 128 & 41 & 182 & 14 & 2.272 & 5.444 & 24.182 \\
\hline
\end{tabular}

Sumber : Kantor BP3K Tondano Barat Kabupaten Minahasa 2016 
Tabel 3. Luas Wilayah Kecamatan menurut Kelurahan

\begin{tabular}{clcc}
\hline No & \multicolumn{1}{c}{ Kelurahan } & Luas (ha) & Prosentase $(\%)$ \\
\hline 1 & Masarang & 262,50 & 11,70 \\
\hline 2 & Tuutu & 315,82 & 14,08 \\
\hline 3 & Roong & 188,00 & 8,38 \\
\hline 4 & Rinegetan & 236,50 & 10,55 \\
\hline 5 & Tounkuramber & 217,50 & 9,70 \\
\hline 6 & Wawalintoan & 176,25 & 7,86 \\
\hline 7 & Rerewokan & 225,00 & 10,03 \\
\hline 8 & Watulambot & 223,00 & 9,94 \\
\hline 9 & Wewelen & 398,00 & 17,75 \\
\hline & Jumlah & $2.242,57$ & 100,00
\end{tabular}

Sumber : Badan Pusat Statistika (BPS) 2016

Luas wilayahnya adalah 2,242,75

km2 Kecamatan ini dikepalai oleh seorang camat dan di setiap kelurahan dipimpin oleh seorang kepala kelurahan.

Hasil persentase di atas menujukkan luas wilayah dari masingmasing desa yang ada di Kecamatan Tondano Barat. Dapat dilihat pada gambar diagram diatas. Luas wilayah desa Tuutu berada pada urutan ke dua dengan hasil persentase luas wilayah $14,08 \%$ setelah desa Wewelan yang berada pada urutan pertama dengan hasil persentase luas wilayahnya terbesar yaitu $17,75 \%$ sedangkan untuk desa Roong merupakan wilayah yang terkecil dengan luas wilayah $8,38 \%$.

\section{Tingkat Umur Responden}

Dari segi umur hampir seluruhnya, yaitu sebanyak $64,91 \%$ ada dalam umur yang produktif. (Tabel 4). Oleh karenanya, peluang untuk diterimanya inovasi oleh para responden tergolong tinggi. Menurut Rogers dan Shoemakers (1986), semakin muda seseorang, dan ada dalam usia yang produktif akan lebih responsif dalam menerima inovasi dibandingkan dengan orang yang telah lanjut.

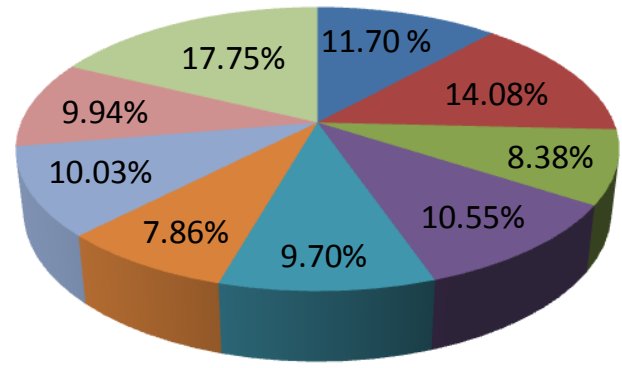

- Masawa-Sawangan

- Tuutu

Roong

- Rinegetan

- Tounkuramber

- Wawalintoan

Renewokan

Watulambot

Wewelan

Gambar 1. Persentase Luas Wilayah Kecamatan Tondano Barat 
Tabel 4. Karakteristik Responden Berdasarkan Umur

\begin{tabular}{cccc}
\hline No & Kategori Responden Berdasarkan Umur & Jumlah (orang) & Persentase (\%) \\
\hline 1. & $15-55$ & 37 & 64,91 \\
2. & $56-70$ & 20 & 35,08 \\
\hline & Jumlah & 57 & 100 \\
\hline
\end{tabular}

Tabel 5. Karakteristik Responden Berdasarkan Jenis Kelamin

\begin{tabular}{clcc}
\hline No & \multicolumn{1}{c}{ Jenis Kelamin } & Jumlah (orang) & Persentase \\
\hline 1. & Laki-Laki & 48 & 84,21 \\
2. & Perempuan & 9 & 15,78 \\
\hline
\end{tabular}

\begin{tabular}{ccc}
\hline Jumlah & 57 & 100 \\
\hline & pelapisan atas dasar seksualitas ini,
\end{tabular}

Faktor jenis kelamin mempengaruhi keinginan dan kemampuan masyarakat untuk berpartisipasi. Menurut Soedarno et.al (1992) dalam Yulianti (2000:34), bahwa di dalam sistem Hal ini dapat terlihat dari jumlah peternak laki - laki sebanyak 48 orang $(84,21 \%)$ dan jumlah wanita sebanyak 9 orang $(15,78 \%)$ dari total responden penelitian yang dilakukan. Perbedaan jumlah peternak laki- laki dan perempuan dapat dilihat pada Tabel 5.

Hasil penelitian menunjukan data pendidikan dari anggota kelompok ternak itik di desa Tuutu adalah SMA $(50,87 \%)$, SMP $(28,07 \%)$ dan SD $(21,05 \%)$. Tingkat pendidikan juga berpengaruh terhadap keberhasilan usaha peternakan. Seperti yang dikemukakan oleh Direktorat Jenderal Peternakan (1997), bahwa tingkat golongan pria memiliki hak istimewa dibandingkan golongan wanita. Dengan demikian maka kecenderungannya, kelompok pria akan lebih banyak berpartisipasi.

pendidikan dari petani peternak juga menentukan keberhasilan usaha peternakan karena dengan berbekal pengetahuan yang cukup melalui jenjang pendidikan maka akan turut mempengaruhi produktivitas usaha peternakan sehingga peran sumberdaya manusia dalam pembangunan peternakan merupakan unsur yang sangat penting.

\section{Tingkat Kepemilikan Ternak}

Pada Tabel 7, dapat digambarkan tentang kepemilikan ternak itik berdasarkan narasumber. Ternyata kepemilikan usaha ternak itik di 
Kecamatan Tondano Barat menunjukan bahwa $38(66,66 \%)$ narasumber memiliki ternak bersama di dalam kelompok peternak, 14 (24,56\%) kepemilikan ternak itik dengan hasil pembelian, kepemilikan dari turun temurun atau dari warisan berjumlah 5 (8,77\%), dan hasil menunjakan bahwa usaha ternak itik di Kecamatan Tondano Barat belum pernah mendapat bantuan dari pemerintah secara langsung.

\section{Pengalaman Beternak}

Pengalaman peternak dalam beternak itik dapat dijelaskan pada Tabel 8, dimana ada usaha yang dilakukan sejak
20 tahun yang lalu dan ada peternak yang baru beternak sejak 2 tahun yang lalu. Hal ini mengambarkan bahwa kelompok peternak di Tondano Barat terus berkembang dengan adanya pertambahan kelompok tersebut. Pertambahan kelompok usaha peternak itik dari tahun ke tahun, menunjukan bahwa usaha peternakan itik di Tondano Barat dapat berkembang.

Usaha peternakan itik di Tondano Barat menunjukan adanya perkembangan, dilihat dari adanya pertambahan kelompok peternak berjumlah 42 orang dalam kelompok $(73,67 \%)$ pada 10 tahun terakhir.

Tabel 7. Kepemilikan Ternak Itik Berdasakan Karakteristik Narasumber

\begin{tabular}{llcc}
\hline No & \multicolumn{2}{c}{ Kategori Jumlah Kepemilikan Ternak } \\
Itik (ekor) & Jumlah (orang) & Persentase (\%) \\
\hline 1. & Bantuan & 0 & 0 \\
2. & Warisan & 5 & 8,77 \\
3. & Gadungan( bagi hasil) & 38 & 66,66 \\
4. & Dibeli & 14 & 24,56 \\
\hline & & 57 & 100 \\
\hline
\end{tabular}

Tabel 8. Karakteristik Responden Berdasakan Pengalaman Beternak

\begin{tabular}{ccccc}
\hline No & & Lama Usaha & Jumlah (orang) & Persentase (\%) \\
\hline 1. & 2 Tahun & 27 & 47,36 \\
2. & 5 Tahun & 15 & 26,31 \\
3. & 10 Tahun & 1 & 1,75 \\
4. & 20 Tahun & 14 & 24,56 \\
\hline & & 57 & 100 \\
\hline
\end{tabular}


Selanjutnya Tabel 8 . dapat menjelaskan bahwa usaha beternak itik baru dijalankan sekitar 2 tahun yang lalu untuk 27 orang $(47,36 \%)$ dikarenakan sebelum menjadi peternak itik yang tergabung didalam kelompok peternak, anggota-anggota peternak itik tersebut sebagai petani dan usaha peternakan itik masih sebagai usaha sampingan.

Peranan kelompok sebagai kelas belajar adalah fungsi kelompok sebagai media untuk meningkatkan pengetahuan, keterampilan dan sikap dari para anggotanya. Beberapa aspek yang mendukung berfungsinya kelompok peternak sebagai kelas belajar, yang pertama adalah kelompok peternak telah rutin di dalam mengadakan pertemuan dikelompoknya.

Kelompok umumnya memiliki agenda pertemuan sebulan sekali di kelompok. Hal ini dapat berjalan secara berkelanjutan,karena selama satu sampai tiga tahun terakhir kelompok telah biasa

Tabel 9. Karakteristik Responden Berdasarkan Peranan Kelompok Terhadap Usaha Pengembangan Ternak Itik

\begin{tabular}{|c|c|c|c|}
\hline No & Peranan Dinamika Kelompok & Jumlah (orang) & Persentase $(\%)$ \\
\hline & Setuju & 56 & 98,24 \\
\hline & Kurang Setuju & 0 & 0 \\
\hline & Tidak Setuju & 0 & 0 \\
\hline & Jarang & 1 & 1,75 \\
\hline & Tidak Pernah & 0 & 0 \\
\hline & Jumlah & 57 & 100 \\
\hline
\end{tabular}


Berdasarkan hasil penelitian menunjukkan bahwa peranan kelompok peternak terhadap usaha pengembangan ternak itik berdasarkan narasumber di Kecamatan Tondano Barat menunjukan respons yang sangat baik. Pada Tabel 9. Menujukan bahwa anggota-anggota kelompok yang menjadi narasumber (informan) dalam penelitian ini memberikan jawaban setuju $(98,24 \%$ atau 56 narasumber) kelompok peternak berpengaruh dalam pengembangan usaha ternak itik di dalam kelompok peternak, sedangkan $(1,75 \%$ atau 1 narasumber $)$ mengatakan jarang kelompok peternak dapat memberikan pengaruh terhadap usaha peternak itik, atau usaha peternak itik dapat maju dan berkembang tanpa bergabung dalam kelompok peternak.

Hasil ini menunjukan bahwa sebagian besar anggota dalam kelompok peternak itik di Kecamatan Tondano Barat menegaskan bahwa peran atau fungsi kelompok sangat menunjang dalam keberhasilan kelompok. Hal ini sesuai dengan penelitian.

\section{Kelompok Tani}

Menurut Hermanto dan Swastika (2011), kelompok tani merupakan kelembagaan di tingkat petani yang di bentuk secara langsung mengorganisir para petani dalam berusaha tani. Selanjutnya menurut Wahyuni (2003), kelompok tani dibentuk berdasarkan suara keputusan dan dimaksudkan sebagai wadah komunikasi antar petani, serta antar petani dengan kelembagaan. Sedangkan menurut (Syahyuti,2007) Kelompok tani merupakan lembaga yang menyatukan para petani secara horizontal dan dapat dibentuk beberapa unit dalam satu desa, bisa berdasarkan komoditas. Kelompok tani adalah kumpulan petani/peternak yang dibentuk atas dasar kesamaan kepentingan, kesamaan kondisi lingkungan social, ekonomi dan sumberdaya, kesamaan komuditas, dan keakraban untuk meningkatkan dan mengembangkan usaha anggota Mutmainah dan Sumardjo (2014).

\section{KESIMPULAN}

Berdasarkan hasil penelitian menunjukkan bahwa Semua kelompok peternak itik di desa Tuutu Kecamatan Tondano Barat Kabupaten Minahasa berperan dalam pengembangan usaha ternak itik, karena dalam pengambilan keputusan, selalu melibatkan kelompok. Kelompok-kelompok tersebut adalah kelompok Masawa-Sawangan, Tougela, Esa Toroan Waya dan Toubeke.

\section{DAFTAR PUSTAKA}

Agustina A. 2008. Identifikasi Kelas Kemampuan Kelompok Tani Ternak Kecamatan Herlang Kabupaten Bulu Kumba. Jurnal Ilmu Ternak, 8 (1) : 77-82. 
Fakultas Peternakan Universitas Hasanudin.

BPS. 2017. Minahasa dalam angka. Tondano. Sulut.

Direktorat Jenderal Peternakan. 1997 Petunjuk Pelaksanaan Pembinaan Kelompok Tani Ternak. Jakarta

Dinas Peternakan. 1998. Laporan Pembinaan Kelompok Tani Program Deliver di Kabupaten Minahasa. Manado.

Hermanto K. S. dan D. Swastika. 2011. Penguatan Kelompok Tani: Langka Awal Peningkatan Kesejahteraan Petani. Jurnal Analisis Kebijakan Pertanian. (9) : 371-390.

Kateran, D. D. 2002. Kebutuhan Gizi Itik Petelur dan Pedaging. Wartozoa. 12 (2) : 37-46.

Mutmainah, R dan Sumardjo. 2014. Peran Kepemimpinan Kelompok Tani dan Efektivitas Pemberdayaan Petani.
Jurnal Sosiologi Pedesaan. 2 (3) : 185-199.

Rogers, Everttem; Shoemakers 1986. Komunikasi, Ternologi, New York: Freeperss.

Suhardiyono, L. 1992. Penyuluhan Petunjuk Bagi Pertanian. Erlangga. Jakarta.

Syahyuti. 2007. Kebijakan Gabungan Kelompok Tani (Gapoktan) Sebagai Kelembagaaan Ekonomi di Pedesaan. Analisis Kebijakan Pertanian 5 (1) : 15-35.

Yulianti, Yoni. 2012. Analisis Partisipasi Masyarakat dalam Pelaksanaan Program Nasional Pemberdayaan Masyarakat (PNPM) Mandiri Perkotaan di Kota Solok (Tesis) Padang: Universitas Andalas.

Wahyuni, S. 2003. Kinerja Kelompok Tani dalam Sistem Usaha Tani dan Metode Pemberdayaannya. Jurnal Libang Pertanian. 22 (1) : 1-8. 